\title{
The Endocannabinoid System Promotes Astroglial Differentiation by Acting on Neural Progenitor Cells
}

\author{
Tania Aguado, ${ }^{1}$ Javier Palazuelos, ${ }^{1}$ Krisztina Monory, ${ }^{2}$ Nephi Stella, ${ }^{3}$ Benjamin Cravatt, ${ }^{4}$ Beat Lutz, ${ }^{2}$ \\ Giovanni Marsicano, ${ }^{2}$ Zaal Kokaia, ${ }^{5}$ Manuel Guzmán, ${ }^{1}$ and Ismael Galve-Roperh ${ }^{1}$ \\ ${ }^{1}$ Department of Biochemistry and Molecular Biology I, School of Biology, Complutense University, 28040 Madrid, Spain, ${ }^{2}$ Max-Planck Institute of \\ Psychiatry, 80804 Munich, Germany, ${ }^{3}$ Department of Pharmacology, Washington University, Seattle, Washington 98195, ${ }^{4}$ The Skaggs Institute for Chemical \\ Biology and Department of Cell Biology, The Scripps Research Institute, La Jolla, California 92037, and 5Laboratory of Neural Stem Cell Biology, Lund \\ Strategic Research Center for Stem Cell Biology and Cell Therapy, University Hospital, SE-221 84 Lund, Sweden
}

Endocannabinoids exert an important neuromodulatory role via presynaptic cannabinoid $\mathrm{CB}_{1}$ receptors and may also participate in the control of neural cell death and survival. The function of the endocannabinoid system has been extensively studied in differentiated neurons, but its potential role in neural progenitor cells remains to be elucidated. Here we show that the $\mathrm{CB}_{1}$ receptor and the endocannabinoid-inactivating enzyme fatty acid amide hydrolase are expressed, both in vitro and in vivo, in postnatal radial glia ( $\mathrm{RC2}^{+}$ cells) and in adult nestin type $\mathrm{I}\left(\right.$ nestin ${ }^{+} \mathrm{GFAP}^{+}$) neural progenitor cells. Cell culture experiments show that $\mathrm{CB}_{1}$ receptor activation increases progenitor proliferation and differentiation into astroglial cells in vitro. In vivo analysis evidences that, in postnatal $\mathrm{CB}_{1}{ }^{-1-}$ mouse brain, progenitor proliferation and astrogliogenesis are impaired. Likewise, in adult $\mathrm{CB}_{1}$-deficient mice, neural progenitor proliferation is decreased but is increased in fatty acid amide hydrolase-deficient mice. In addition, endocannabinoid signaling controls neural progenitor differentiation in the adult brain by promoting astroglial differentiation of newly born cells. These results show a novel physiological role of endocannabinoids, which constitute a new family of signaling cues involved in the regulation of neural progenitor cell function.

Key words: cannabinoid; neural progenitor; proliferation; astrogliogenesis; radial glia; $\mathrm{CB}_{1}$ receptor

\section{Introduction}

The recent identification of neural progenitor (NP) cells resident in the subventricular zone, the dentate gyrus of the hippocampus, and the olfactory bulb has provided a biological explanation for the neurogenic process that occurs in these restricted adult brain areas (Alvarez-Buylla and Lim, 2004; Lie et al., 2004). Cells expressing certain markers of astroglial cells, such as glial fibrillary acidic protein (GFAP), act as multipotent self-renewing progenitors that can differentiate into the major brain cellular lineages (Doetsch et al., 1999; Laywell et al., 2000; Seri et al., 2001). For instance, selective cell ablation by GFAP-driven thymidine kinase expression and ganciclovir administration elegantly demonstrated the nature of postnatal and adult brain NPs (Imura et al.,

Received March 4, 2005; revised Nov. 16, 2005; accepted Dec. 21, 2005.

This research was supported by Ministerio de Educación y Ciencia, Comunidad Autónoma de Madrid, and Fundación Científica de la Asociación Española Contra el Cáncer (M.G., I.G.-R.), Deutsche Forschungsgemeinschaft and Hertie Foundation (B.L.), National Institutes of Health (N.S.), a Marie Curie fellowship (K.M.), and Swedish Research Council and Swedish Foundation for Strategic Research (Z.K.). I.G.-R. is a research associate supported by the Ramón y Cajal Program of Ministerio de Educación y Ciencia, and T.A. is supported by Comunidad Autónoma de Madrid. We are indebted to our laboratory colleagues for fruitful scientific discussions, to A. Martínez-Serrano, B. Navarro, and I. Azcoitia for excellent advice in the in vivo experiments, and to A. Eguía, B. Fackelmeier, T. Orschmann, and B. Wölfel for technical assistance.

Correspondence should be addressed to Ismael Galve-Roperh, Biochemistry and Molecular Biology I, School of Biology, Complutense University, Calle Jose Antonio Novais, 28040 Madrid, Spain. E-mail: igr@quim.ucm.es.

K. Monory's and B. Lutz's present address: Institute of Physiological Chemistry, Johannes Gutenberg University Mainz, Duesbergweg 6, 55099 Mainz, Germany.

DOI:10.1523/JNEUROSCI.3101-05.2006

Copyright $\odot 2006$ Society for Neuroscience $\quad$ 0270-6474/06/261551-11\$15.00/0
2003; Garcia et al., 2004). The existence of this adult GFAPpositive NP cell subpopulation is in agreement with the ability of radial glia to act as parental cells (Malatesta et al., 2000; Noctor et al., 2001) besides their well known migratory scaffold role during cortex development (Rakic, 2003). During development, radial progenitors evolve to GFAP-expressing cells with a concomitant decrease in RC2 expression (Tramontin et al., 2003; Merkle et al., 2004). In particular, double nestin ${ }^{+} \mathrm{GFAP}^{+}$cells (type I cells) are proposed to constitute the adult neural stem cell population as a continuum of the embryonic neural stem cell compartment (Alvarez-Buylla and Lim, 2004; Kempermann et al., 2004).

Although many extracellular signals are known to be involved in the regulation of NP cell proliferation and differentiation (Temple, 2001; Ross et al., 2003), the precise mechanisms involved in cell fate determination remain to be fully elucidated. Growth factors, such as epidermal growth factor (EGF) and basic fibroblast growth factor (bFGF), act as key regulators of NP cell proliferation and differentiation (Temple, 2001). In addition, a variety of signals participate in the regulation of NP differentiation to either neurogenesis or gliogenesis (Ross et al., 2003; Ever and Gaiano, 2005). The endocannabinoids (eCBs) anandamide [ $\mathrm{N}$-arachidonoylethanolamine (AEA)] and 2-arachidonoylglycerol (2AG), the endogenous counterparts of plant-derived cannabinoids, exert a neuromodulatory role by controlling neurotransmitter release via presynaptic $\mathrm{CB}_{1}$ receptors (Piomelli, 2003). Cannabinoids may also take part in the control of neural 
cell fate, thereby modulating the balance between cell death and survival (Mechoulam et al., 2002; Guzmán, 2003). eCBs are generated on demand as a consequence of brain injury (Mechoulam et al., 2002), and $\mathrm{CB}_{1}$ receptor engagement is responsible for their neuroprotective action (Marsicano et al., 2003). Moreover, cannabinoid administration protects neurons from different brain insults, such as ischemia, glutamatergic excitotoxicity, oxidative stress, and trauma (Mechoulam et al., 2002). $\mathrm{CB}_{1}$ expression is developmentally regulated, with a peak of expression in the rat hippocampus that coincides with the initiation of gliogenesis in vivo (Fernández-Ruiz et al., 2001). The function of the eCB system has been extensively studied in differentiated neurons, and its potential implication in the regulation of NP cell fate has been suggested (Rueda et al., 2002; Jin et al., 2004; Aguado et al., 2005). However, its precise role in the regulation of cell lineage commitment and NP differentiation remains to be elucidated. Together, these evidences prompted us to study whether NP cells express a functional eCB system and, if so, whether it regulates NP differentiation.

\section{Materials and Methods}

Materials. The following materials were kindly donated: nestin-green fluorescent protein (GFP) transgenic mice (G. Enikolopov, Cold Spring Harbor Laboratory, Cold Spring Harbor, New York, NY), GL1-pGL3 (T. Taga, Kumamoto University, Kumamoto, Japan), SR141716 [N-piperidino-5-(4-chlorophenyl)1-(2,4-dichlorophenyl)-4-methyl-3-pyrazole carboxamide] (Sanofi-Aventis, Montpellier, France), anti-mouse $\mathrm{CB}_{1}$ polyclonal antibody (K. Mackie, Washington University, Seattle, WA), anti-mouse polysialylated neural cell adhesion molecule (PSA-NCAM) monoclonal antibody (I. Azcoitia, Complutense University, Madrid, Spain), anti-mouse phosphorylatedS55 vimentin monoclonal 4A4 antibody (V. Cerdeño, University of California San Francisco, San Francisco, CA), neuroepithelial expression reporter vector (pNERV) nestin- $\beta$ galactosidase $(\beta$-gal) reporter (Panchision et al., 2001), and monoclonal anti-O4 antibody (A. Rodríguez-Peña, Consejo Superior de Investigaciones Científicas, Madrid, Spain) (Sommer and Schachner, 1981). Cyclohexyl carbamic acid 3'-carbamoyl-biphenyl-3-yl ester (URB597) and 2AG were from Cayman Chemicals (Ann Arbor, MI), mouse monoclonal anti-nestin, anti-vimentin, and rabbit poly-

clonal anti-fatty acid amide hydrolase (FAAH) antibodies were from Chemicon (Temecula, CA), rabbit monoclonal anti-Ki67 (SP6) antibody from was LabVision (Fremont, CA), and rabbit polyclonal antiglutamate-aspartate transporter (GLAST) was from Alpha Diagnostic (San Leandro, CA). Recombinant human EGF and bFGF were from R \& D Systems (Minneapolis, MN). WIN-55,212-2 [R-(+)-(2,3-dihydro-5methyl-3-[(4-morpholinyl)methyl]pyrol[1,2,3-de]-1,4- benzoxazin-6differentiated astroglial cells $(A)$.
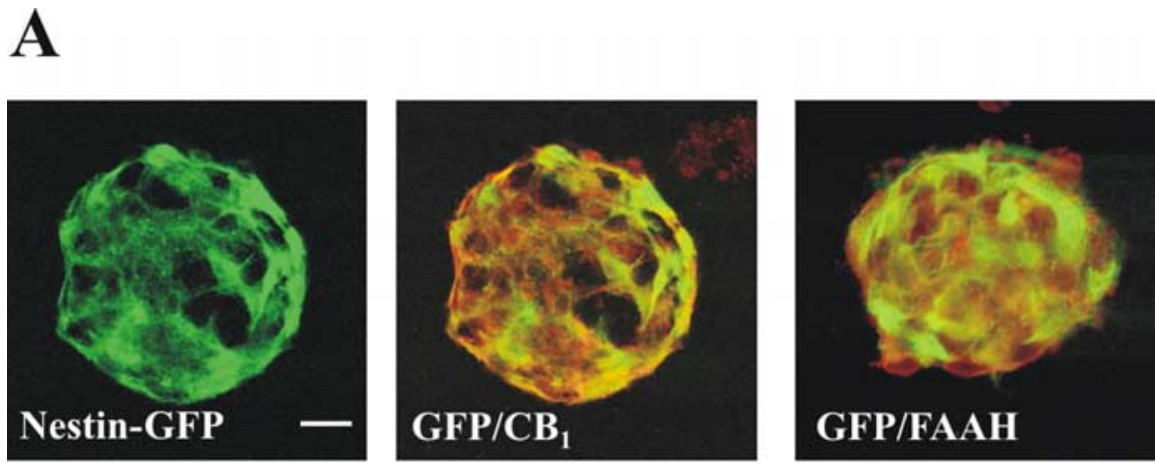

\section{B}
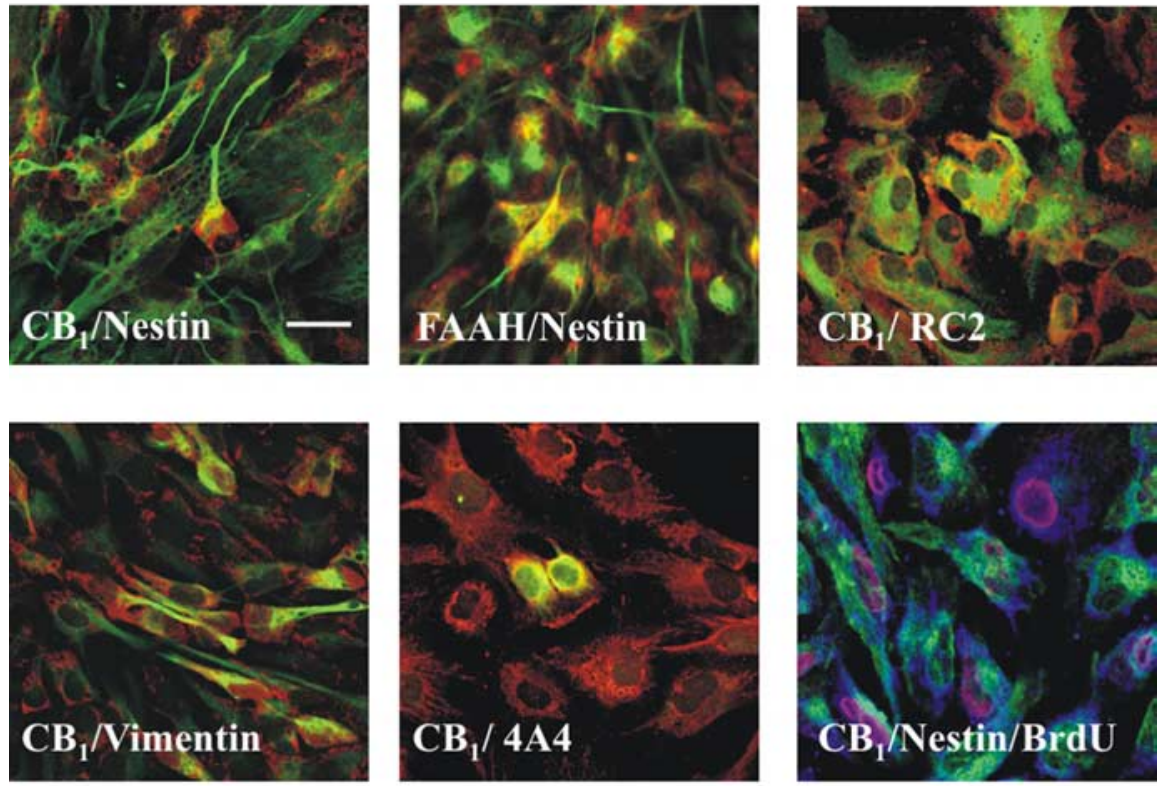

Figure 1. The endocannabinoid system is expressed in postnatal neural progenitors. $A$, Immunofluorescence was performed to assess $C_{1}$ and FAAH (red) expression in nestin-GFP-derived neurospheres. Scale bar, $20 \mu \mathrm{m}$. $\boldsymbol{B}$, Immunofluorescence was performed with $\mathrm{CB}_{1}$ or $\mathrm{FAAH}$ antibodies (red) in combination with nestin, $\mathrm{RC2}$, vimentin, or phosphorylated vimentin (4A4) antibodies (green). In addition, triple labeling was performed with $\mathrm{CB}_{1}$ (blue), nestin (green), and BrdU (red) antibodies. Scale bars, $20 \mu \mathrm{m}$. $C$, The presence of $C_{1}$ receptor and FAAH mRNA was determined by RT-PCR in NPs, differentiated neurons (N), and

yl)(1-naphthalenyl) methanone monomethanesulfonate], AEA, mouse monoclonal anti- $\beta$-tubulin III, anti-GFAP, and anti- $\alpha$-tubulin antibodies were from Sigma (St. Louis, MO). Monoclonal anti-RC2 antibody was from the Developmental Studies Hybridoma Bank (University of Iowa, Iowa City, IA).

Neural progenitor cell culture. NPs were obtained from the dissected cortices of 2-d-old rat pups and grown in chemically defined medium formed by Dulbecco's modified Eagle's and F-12 media supplemented 
A

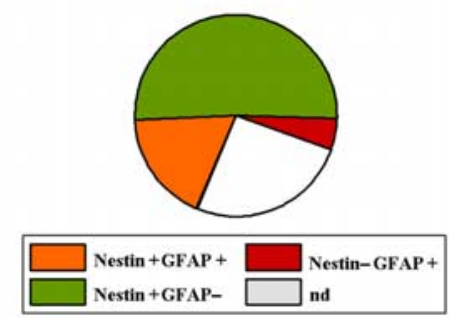

B

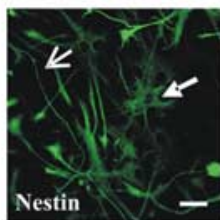

D0

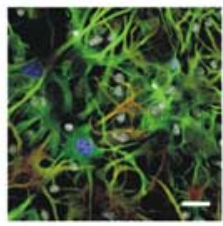

Nestin/GFAP/Ki67/Hoechst
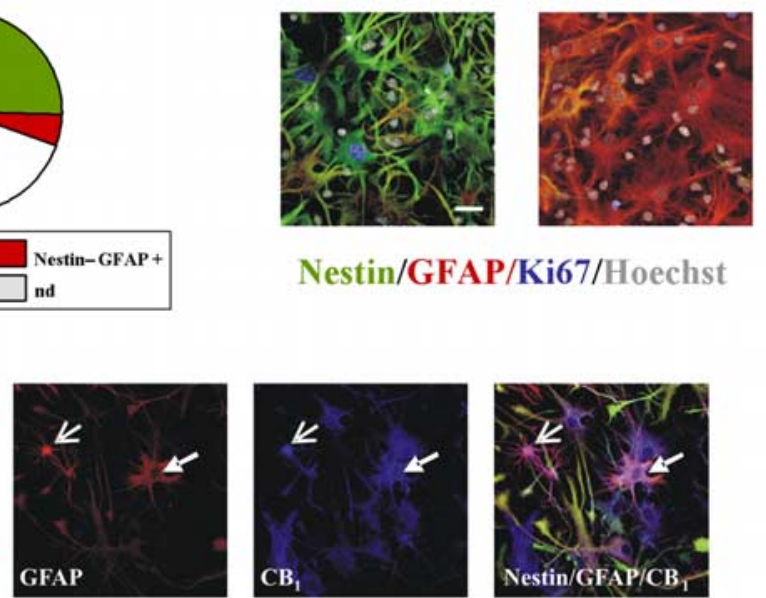

\begin{tabular}{|l|c|c|}
\hline & CB $_{1}$ expression (\%) & Cell proliferation (\%) \\
\hline Nestin $^{+}$GFAP $^{+}$ & $49 \pm 14$ & $136 \pm 11^{*}$ \\
\hline Nestin $^{+}$GFAP- $^{-}$ & $10 \pm 4$ & $95 \pm 8$ \\
\hline Nestin GFAP $^{+}$ & $25 \pm 8$ & $94 \pm 15$ \\
\hline Nestin-GFAP- & $11 \pm 5$ & n.d. \\
\hline
\end{tabular}

C

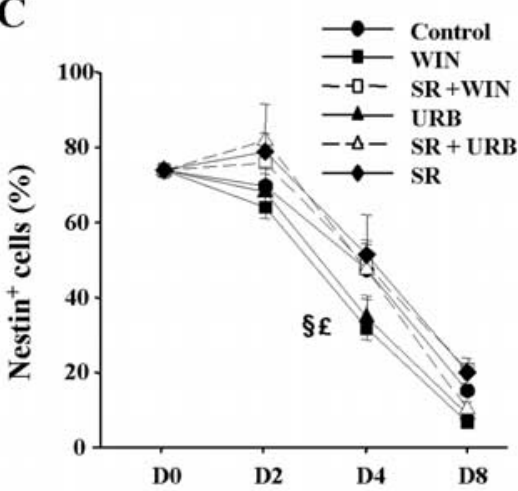

D

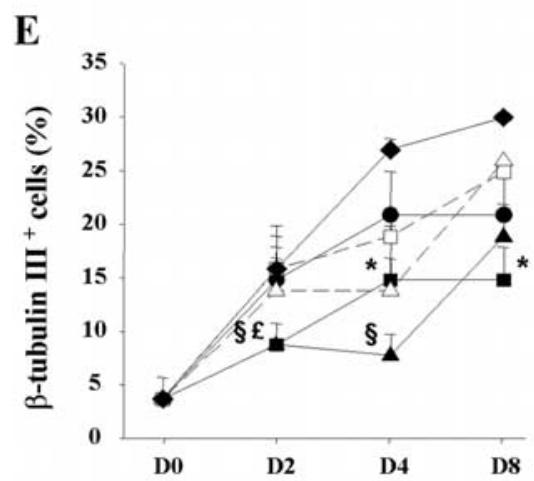

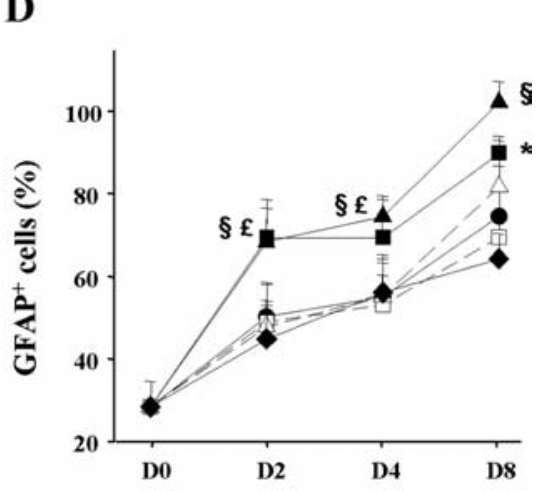

F

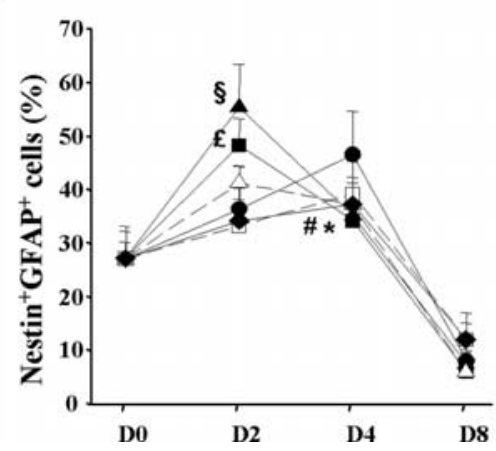

Figure 2. Characterization of postnatal progenitor proliferation and astroglial differentiation. $\boldsymbol{A}$, Distribution of the phenotypic analysis with the indicated cell markers of proliferating $\left(\mathrm{Ki}_{6}{ }^{+}\right)$cells after $16 \mathrm{~h}$ of differentiation. Representative immunofluorescence pictures of NPs at different stages of differentiation using the indicated markers (n.d., not determined). Scale bar, $30 \mu \mathrm{m} . \boldsymbol{B}_{1}, \mathrm{CB}_{1}$ receptor distribution in the different cellular phenotypes (as above). Representative nestin ${ }^{+} \mathrm{GFAP}^{+} \mathrm{CB}_{1}{ }^{+}$(filled arrow) and nestin ${ }^{-} \mathrm{GFAP}^{+} \mathrm{CB}_{1}{ }^{+}$ cells (open arrow) are shown. Scale bar, $30 \mu \mathrm{m}$. Quantification of $\mathrm{CB}_{1}$ distribution compared with the proliferative effect induced by WIN-55,212-2 for each cell type. Significantly different from controls, ${ }^{*} p<0.01$. C $-\boldsymbol{F}$, Cannabinoid impact on NP differentiation. Quantification of the percentage of nestin ${ }^{+}(\boldsymbol{C}), \mathrm{GFAP}^{+}(\boldsymbol{D}), \beta$-tubulin $\mathrm{II}^{+}(\boldsymbol{E})$, and nestin ${ }^{+} \mathrm{GFAP}^{+}(\boldsymbol{F})$ cells versus total cell number at the indicated differentiation times in the presence of vehicle, WIN-55,212-2, or URB597 alone or with SR141716, and SR141716 alone. Results correspond to three independent experiments. Significant differences between cannabinoid-treated versus control cells are shown. *WIN-

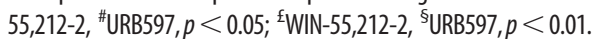

with N2 (Invitrogen, Carlsbad, CA), 0.6\% glucose, nonessential amino acids, 50 mM HEPES, $2 \mu \mathrm{g} / \mathrm{ml}$ heparin, $20 \mathrm{ng} / \mathrm{ml} \mathrm{EGF}$, and $20 \mathrm{ng} / \mathrm{ml}$ bFGF. Clonal neurospheres were derived from nonadherent cultures of NPs (1000 cells/ml). Adherent NP cultures in chemically defined medium were grown in polyornithine-coated plates, and differentiation experiments were performed during the indicated times in the presence of the indicated stimuli after overnight growth factor deprivation. Differentiation experiments of at least three independent cultures were performed by quantification of the cells that express the indicated antigens and total cells stained with Hoechst 33258. A minimum of 10 fields were scored in a double-blinded manner to minimize subjective interpretations. Quantified fields were selected randomly by visualizing total cells with microscope Hoechst filter. Clonal analysis was performed by quantification of differentiation of single-cell-derived neurospheres and triple immunofluorescence with anti- $\beta$-tubulin III, GFAP, and $\mathrm{O} 4$ antibodies. Immunofluorescence study of $\mathrm{CB}_{1}$ and FAAH expression was determined in NPs derived from wild-type and nestin-GFP mice ( $\mathrm{Mi}$ gnone et al., 2004). Stock solutions of cellular effectors were prepared in $\mathrm{Me}_{2} \mathrm{SO}$. No significant influence of $\mathrm{Me}_{2} \mathrm{SO}$ on any of the parameters determined was observed at the final concentration used $(0.1 \% \mathrm{v} / \mathrm{v})$. Control incubations included the corresponding vehicle content.

Terminal deoxynucleotidyltransferase-mediated dUTP nick-end labeling staining. NPs after cannabinoid stimulation were fixed in paraformaldehyde at $4^{\circ} \mathrm{C}$, permeabilized with $0.05 \%$ Triton X-100 in PBS, and blocked with $0.5 \%$ BSA-PBS for $30 \mathrm{~min}$. DNA ends were subsequently labeled for $2 \mathrm{~h}$ at $37^{\circ} \mathrm{C}$ in Tris-buffered saline $(50 \mathrm{~mm}$ Tris- $\mathrm{HCl}, \mathrm{pH} 7.2$, and $100 \mathrm{~mm}$ $\mathrm{NaCl}$ ) containing $2 \mathrm{~mm} \mathrm{CoCl}_{2}, 0.1 \mathrm{U} / \mu \mathrm{l}$ terminal deoxynucleotidyltransferase (Invitrogen), and $2.5 \mathrm{pmol} / \mu \mathrm{l}$ biotin-16-dUTP (Boehringer Mannheim, Mannheim, Germany). Finally, cells were incubated for an additional $2 \mathrm{~h}$ with $3.5 \mu \mathrm{g} / \mathrm{ml}$ streptavidin-AlexaFluor 488 (Invitrogen) in $0.1 \%$ BSA-PBS.

Fluorescence-activated cell sorting analysis. NPs at passage 3 were dissociated with accutase (Innovative Cell Technologies, San Diego, CA) following the instructions of the manufacturer, and $500 \times 10^{3}$ cells per condition were fixed and permeabilized for intracellular staining with $0.5 \%$ saponin in $\mathrm{PBS}$, and unspecific binding was blocked using $2 \%$ goat serum in PBS. Primary antibodies and their corresponding controls were incubated for $30 \mathrm{~min}$ at $4^{\circ} \mathrm{C}$ in $0.1 \%$ saponin-PBS and, after washing, were incubated with the corresponding secondary antibodies. Ten thousand cells per recording were analyzed using an FACSCalibur flow cytometer.

Gene promoter reporter activity. Adherent cortical NP cells were transfected with GF1pGL3 or pNERV using Lipofectamine 2000 (Invitrogen) and, after $1 \mathrm{~d}$, were incubated with the indicated agents as described in the figure legends. Assay of GFAP promoter-driven lucif- 
erase activity was performed following the instructions of the manufacturer using Promega (Madison, WI) luciferase assay and a Lumat LB9507 luminometer (Berthold Technologies, Bad Wildbad, Germany). Transcriptional activation of the GFAP promoter was confirmed in some experiments by inclusion of renilladerived luciferase activity as internal transfection control and determination by the DualLuciferase Reporter Promega assay system. $\beta$-gal activity was determined according to standard procedures.

$m R N A$ detection and quantification. RNA was obtained with the RNeasy Protect kit (Qiagen, Hilden, Germany) using the RNase-free DNase kit. cDNA was subsequently obtained using the Superscript First-Strand cDNA synthesis kit (Roche Products, Welwyn Garden City, UK), and amplification of CDNA was performed with the following primers: rat $\mathrm{CB}_{1}$ sense, TCT CTG GAA GGC TCA CAG; rat $\mathrm{CB}_{1}$ antisense, TGT CTG TGG ACA CAG ACA TG (522 bp product); rat FAAH sense, TGG GCC CTG CTC TGG ATT TG; and rat FAAH antisense, CAG AGC TGG CGA ATG AAC GAC (340 bp product). $\mathrm{CB}_{1}$ PCR reactions were performed using the following conditions: $93^{\circ} \mathrm{C}$ for $1 \mathrm{~min}$, two rounds $\left(30 \mathrm{~s}\right.$ at $59^{\circ} \mathrm{C}, 1 \mathrm{~min}$ at $72^{\circ} \mathrm{C}$, and $30 \mathrm{~s}$ at $93^{\circ} \mathrm{C}$ ), two rounds $\left(30 \mathrm{~s}\right.$ at $57^{\circ} \mathrm{C}, 1 \mathrm{~min}$ at $72^{\circ} \mathrm{C}$, and $30 \mathrm{~s}$ at $93^{\circ} \mathrm{C}$ ), and 35 cycles $\left(30 \mathrm{~s}\right.$ at $55^{\circ} \mathrm{C}, 1$ min at $72^{\circ} \mathrm{C}$, and $30 \mathrm{~s}$ at $93^{\circ} \mathrm{C}$ ). FAAH PCR conditions were as follows: $3 \mathrm{~min}$ at $96^{\circ} \mathrm{C}$ and 35 cycles $\left(30 \mathrm{~s}\right.$ at $95^{\circ} \mathrm{C}, 30 \mathrm{~s}$ at $65^{\circ} \mathrm{C}$, and $1 \mathrm{~min}$ at $72^{\circ} \mathrm{C}$ ). Finally, after a final extension step at $72^{\circ} \mathrm{C}$ for $5 \mathrm{~min}, \mathrm{PCR}$ products were separated on $1.5 \%$ agarose gels. Real-time quantitative PCR was performed with Taqman probes obtained from Applied Biosystems (Foster City, CA). Amplifications were run in a 7700 Realtime PCR system and obtained values adjusted using 18S RNA levels as reference.

Western blot. Western blot analysis was performed as described previously (Galve-Roperh et al., 2000). Cleared cell extracts were subjected to SDS-PAGE and transferred to polyvinylidene difluoride membranes. After incubation with anti-GFAP or anti-nestin antibody, blots were developed with horseradish peroxidasecoupled secondary antibodies and enhanced chemiluminescence detection kit. Loading controls were performed with an anti- $\alpha$-tubulin antibody. Densitometric quantification of the luminograms was performed using a GS-700 Imaging Densitometer (Bio-Rad, Hercules, $\mathrm{CA}$ ) and MultiAnalyst software (Bio-Rad).

Animals and drug treatment. $\mathrm{CB}_{1}$ (Marsicano et al., 2002) and FAAH (Cravatt et al., 2001) knock-out mice generation has been described previously. Postnatal day 2 mice pups were obtained from heterozygote crossings, and mothers were injected with $100 \mathrm{mg} / \mathrm{kg}$ 5-bromo-2' deoxyuridine (BrdU) on gestational day 18.5. After dissection, brains were fixed, and the corresponding tail DNA was used for genotyping. Determination of postnatal in vivo cell fate was performed with $C B_{1}^{-/-}$and $C B_{1}^{+/+}$pups $(n=$ 4 each). Adult $\mathrm{CB}_{1}$ and FAAH knock-out mice (3 months old) and their respective wild-type littermates were injected intraperitoneally with
A
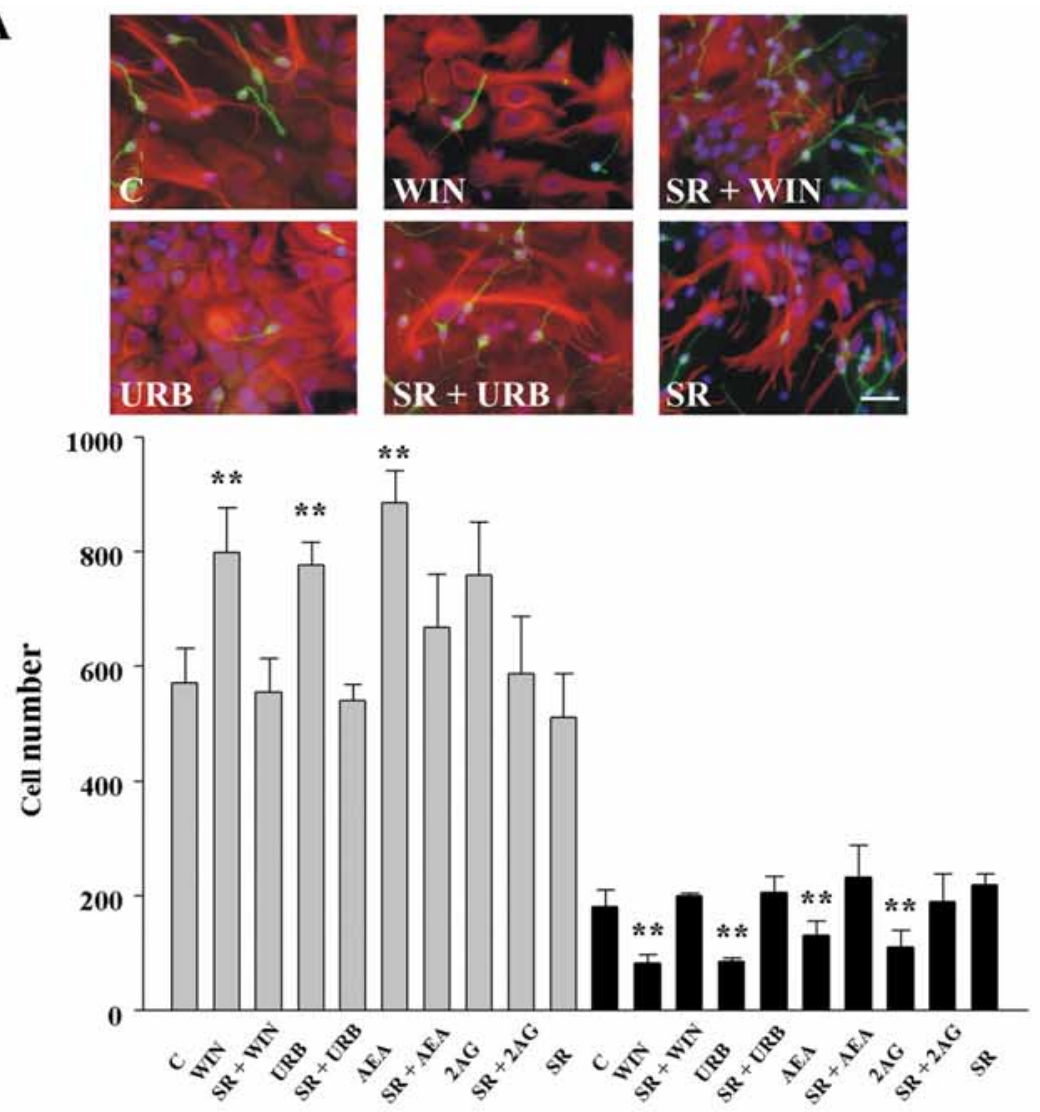

B
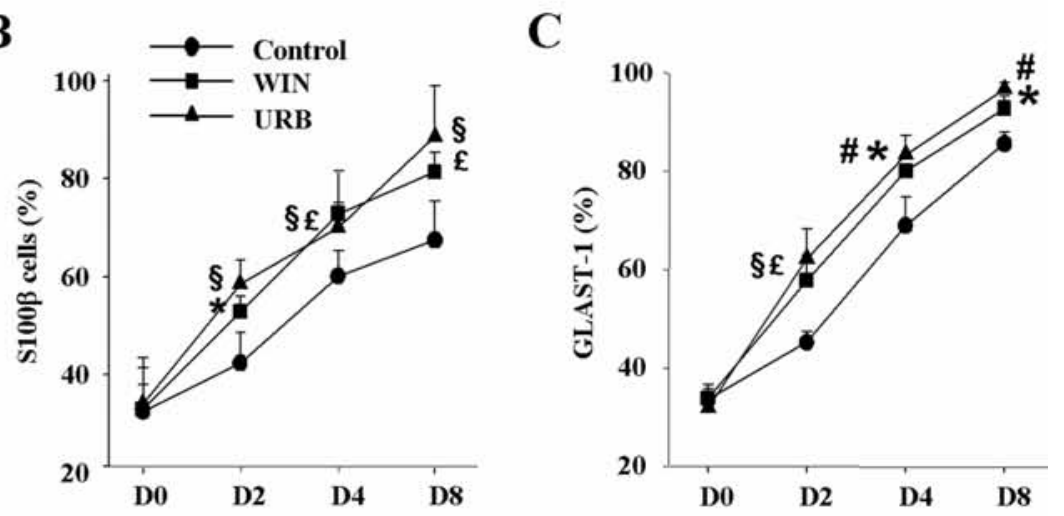

D

\begin{tabular}{|c|c|c|c|c|c|}
\hline Cell types & NAO & NA & AO & N & A \\
\hline Basal & & & & & \\
NSP/total & $25 / 37$ & $3 / 37$ & $4 / 37$ & $3 / 37$ & $2 / 37$ \\
NSP (\%) & 68 & 8 & 11 & 8 & 5 \\
\hline WIN & & & & & \\
NSP/total & $27 / 45$ & $4 / 45$ & $5 / 45$ & $4 / 45$ & $5 / 45$ \\
NSP (\%) & 60 & 9 & 11 & 9 & 11 \\
\hline
\end{tabular}
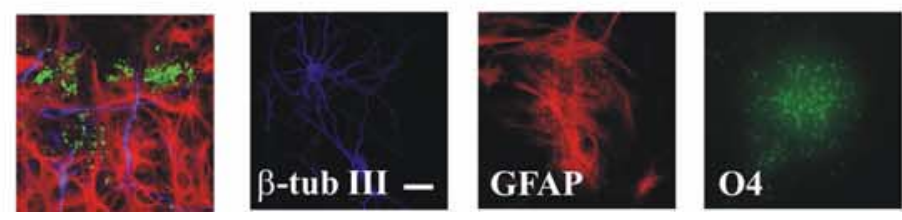

Figure 3. Cannabinoids promote astroglial differentiation in vitro. A, Immunofluorescence with anti- $\beta$-tubulin III (green) and GFAP (red) antibodies after a $48 \mathrm{~h}$ differentiation period of NP cells in the presence of vehicle (C),30 $\mathrm{nm}$ WIN-55,212-2 alone or with $2 \mu \mathrm{m}$ SR141716, 30 nм URB597 alone or with SR141716, and SR141716 alone. Scale bar, $30 \mu \mathrm{m}$. (Figure legend continues.) 
$50 \mathrm{mg} / \mathrm{kg}$ BrdU daily for $5 \mathrm{~d}$ and then perfused $1 \mathrm{~d}\left(n=3, C B_{1}{ }^{-/-}\right.$and $C B_{1}^{+/+} ; n=4 F_{A A H^{-/-}}$and $\left.F A A H^{+/+}\right)$or $25 \mathrm{~d}\left(n=4, C B_{1}^{-/-}\right.$and $\mathrm{CB}_{1}{ }^{+/+} ; n=3 \mathrm{FAAH}^{-/-}$and $\mathrm{FAAH}^{+/+}$) later. Animal procedures were performed according to the European Union guidelines (86/609/EU) for the use of laboratory animals.

Immunofluorescence and confocal microscopy. Perfusion and immunofluorescence was performed in $7 \mu \mathrm{m}$ postnatal brain sections and $30 \mu \mathrm{m}$ coronal adult brain free-floating sections of mice, as described previously (Rueda et al., 2002; Aguado et al., 2005). Postnatal and adult brain sections were incubated with rat monoclonal anti-BrdU (Abcam, Cambridge, MA), mouse monoclonal anti-neuronal-specific nuclear protein (NeuN) (Sigma), and rabbit polyclonal anti-S100 $\beta$ (Swant, Bellinzona, Switzerland) antibodies, followed by secondary staining for rat, mouse, and rabbit IgGs with highly cross-adsorbed AlexaFluor 594, AlexaFluor 488, and AlexaFluor 647 secondary antibodies (Invitrogen), respectively. Preparations were examined using Laser Sharp 2000 software (Bio-Rad) and a Confocal Radiance 2000 coupled to Axiovert S100 TV microscope (Zeiss, Oberkochen, Germany) with three passes with a Kalman filter and a $1024 \times 1024$ collection box. Neurogenesis and astrogliogenesis were determined in a minimum of five brain sections per animal. A 1-in-6 series of adult hippocampal mouse sections located between 1.3 and 2.1 $\mathrm{mm}$ posterior to bregma were used. The number of cells was normalized to the area of the dentate gyrus of each $30 \mu \mathrm{m}$ section, followed by the determination of the total positive cell number per animal. For studies assessing $\mathrm{CB}_{1}$ receptor and FAAH expression in the hippocampal subgranular zone, TOTO-3 iodide (Invitrogen) was used to stain cell nuclei, except when nestin-GFP sections were used. BrdU ${ }^{+}$cells were counted in the subgranular zone and granule cell layer of the dentate gyrus, and confirmation that BrdU staining revealed proliferating neural progenitors but not DNA-repairing cells was assessed by standard criteria.

$\mathrm{CB}_{1}$ staining was detected with a rabbit polyclonal anti-rat/mouse $\mathrm{CB}_{1}$ antibody directed against the first 77 residues of the protein (Rodriguez et al., 2001). Specificity of $\mathrm{CB}_{1}$ immunoreactivity was corroborated by preabsorption experiments in which $0.5 \mu \mathrm{g}$ of the polyclonal antibody was preincubated with $20 \mu \mathrm{g}$ of the antigenic peptide for $1 \mathrm{~h}$ at $37^{\circ} \mathrm{C}$. In addition, specificity was unequivocally determined using postnatal and adult $C B_{1}^{-1-}$ mice sections, in which no immunoreactivity was observed (data not shown) and allowed us to adjust optimal confocal microscope settings. Quantification of the distribution of $\mathrm{CB}_{1}$ and FAAH was obtained by the use of four postnatal or adult wild-type mice and cell counting of a minimum of 500 cells of the different phenotypes per animal.

Statistical analysis. Results shown represent the means \pm SD of the number of experiments indicated in every case. Statistical analysis was performed by ANOVA. A post hoc analysis was made by the StudentNewman-Keuls test. In vivo data were analyzed by an unpaired Student's $t$ test.

\section{Results \\ Expression of the endocannabinoid system in postnatal neural progenitors}

Several evidences indicate that the eCB system may be expressed by embryonic NP cells (Rueda et al., 2002; Aguado et al., 2005). However, its presence in postnatal NPs has not been assessed yet. NPs derived from nestin-GFP mice were obtained, and $\mathrm{CB}_{1}$ and FAAH expression was determined by immunofluorescence. As shown in the merged images, nestin ${ }^{+}$progenitors express both elements of the eCB signaling system (Fig. $1 A$ ). In addition, post-

(Figure legend continued.) Quantification of the $\mathrm{GFAP}^{+}$(gray bars) and $\beta$-tubulin III ${ }^{+}$(black bars) after differentiation of NPs as above or in the presence of $10 \mu \mathrm{m}$ AEA or $2 \mathrm{AG}$. Results correspond to three independent experiments. ${ }^{*} p<0.05 ;{ }^{* *} p<0.01$. Quantification of the percentage of $S 100 \beta^{+}(\boldsymbol{C})$ or GLAST-1 ${ }^{+}(\boldsymbol{D})$ cells versus total cell number at the indicated times in the presence of vehicle, WIN-55,212-2, or URB597. *WIN-55,212-2, \#URB597, $p<0.05$; ${ }^{\text {} W I N-55,212-2, ~}{ }^{\S}$ URB597, $p<0.01$. D, Clonal analysis of postnatal NP-derived neurospheres indicating the number of clones that generated neurons (N), astrocytes $(A)$, and oligodendrocytes ( 0 ) together with other lineage-restricted clones. Triple immunostaining with $\beta$-tubulin III, GFAP, and 04 antibodies was performed after $8 \mathrm{~d}$ differentiation. Examples of differentiated cells are shown. Scale bar, $20 \mu \mathrm{m}$. natal NPs were obtained, and fluorescence-activated cell sorting analysis revealed a majority of nestin ${ }^{+}$NPs $(75 \pm 2 \%$ of total cells), followed by a glial-like cell component $\left(\mathrm{GFAP}^{+}\right.$cells, $18 \pm$ $6 \%)$ and a minor immature neuronal cell fraction $(\beta$-tubulin $\left.\mathrm{III}^{+}, 6 \pm 2 \%\right) \cdot \mathrm{CB}_{1}$ and FAAH expression was subsequently analyzed by immunofluorescence (Fig. $1 B$ ) and reverse transcription (RT)-PCR (Fig. 1C). NPs were shown to express nestin together with the $\mathrm{CB}_{1}$ receptor and FAAH. Accordingly, RC2- and vimentin-positive cells, common markers of radial glial cells (Pixley and de Vellis, 1984; Rakic, 2003), expressed the $\mathrm{CB}_{1}$ receptor (Fig. $1 \mathrm{~B}$ ). These findings are in agreement with the presence of the receptor in actively dividing progenitors, identified by BrdU incorporation and nestin coexpression, as well as in cells immunostained for phosphorylated vimentin (4A4 antibody) (Fig. $1 B$ ).

\section{Endocannabinoids induce postnatal astroglial differentiation in vitro in a $\mathrm{CB}_{1}$-dependent manner}

The potential influence of cannabinoids in NP cell differentiation was determined in adherent NP cultures differentiated in the absence or presence of these compounds. Because cannabinoids exert a positive action on NP proliferation [ $16 \mathrm{~h}$ incubation with $30 \mathrm{nM}$ WIN-55,212-2 (a synthetic cannabinoid agonist) or $30 \mathrm{nM}$ URB597 (a selective FAAH inhibitor): $158 \pm 17$ and $239 \pm 42 \%$ $\mathrm{BrdU}^{+}$cells, respectively, vs $100 \%$ in vehicle incubations], we identified by immunofluorescence the characteristics of the progenitor cells present in our model (Fig. 2). Quantification of the specific neural markers expressed by $\mathrm{Ki}^{+}{ }^{+}$cells identified the existence of double nestin ${ }^{+} \mathrm{GFAP}^{+}(18 \pm 5 \%)$, nestin ${ }^{+} \mathrm{GFAP}^{-}$ $(51 \pm 7 \%)$, and nestin ${ }^{-}$GFAP $^{+}(5 \pm 2 \%)$ cells. These subpopulations may represent different stages of postnatal NP development (Laywell et al., 2000; Gregg and Weiss, 2003; Imura et al., 2003; Tramontin et al., 2003; Alvarez-Buylla and Lim, 2004), in agreement with the observation that the majority of cells at the initiation of differentiation express vimentin $(87 \pm 10 \%)$. To determine which cell subpopulation responds to cannabinoid stimulation, the expression of $\mathrm{CB}_{1}$ and their proliferative response was determined in each case (Fig. 2 B). Nestin ${ }^{+}$GFAP $^{+}$ cells were shown to constitute the major phenotype of $\mathrm{CB}_{1}$ positive cells, and they responded preferentially to cannabinoidinduced proliferation, whereas the nestin ${ }^{+} \mathrm{GFAP}^{-}$and nestin ${ }^{-} \mathrm{GFAP}^{+}$subpopulations were refractory to cannabinoidinduced proliferation.

The dynamics, under basal conditions, of the different cell populations during the differentiation process of NPs was then analyzed (Fig. $2 C-F$ ). Nestin ${ }^{+}$cell number decreased along time with a parallel increase in $\mathrm{GFAP}^{+}$cells. In addition, $\beta$-tubulin $\mathrm{III}^{+}$cells increased along with differentiation. Oligodendrocytes were also observed (day $8,9 \pm 3 \%$ of total cell number). In addition, analysis of the evolution of the nestin ${ }^{+}$population regarding GFAP expression revealed an early increase in nestin ${ }^{+} \mathrm{GFAP}^{+}$cells that ensued a time-dependent decline. In parallel to their reduction, the more differentiated population of nestin ${ }^{-} \mathrm{GFAP}^{+}$cells increased along time (data not shown).

Cannabinoid incubation during the differentiation process induced a significant progliogenic action and an inhibitory effect on neuronal differentiation. As evidenced by immunofluorescence analysis, WIN-55,212-2, URB597, and the eCB ligands AEA and $2 \mathrm{AG}$ increased the number of $\mathrm{GFAP}^{+}$cells with a concomitant decrease in $\beta$-tubulin $\mathrm{III}^{+}$cells after $2 \mathrm{~d}$ of 

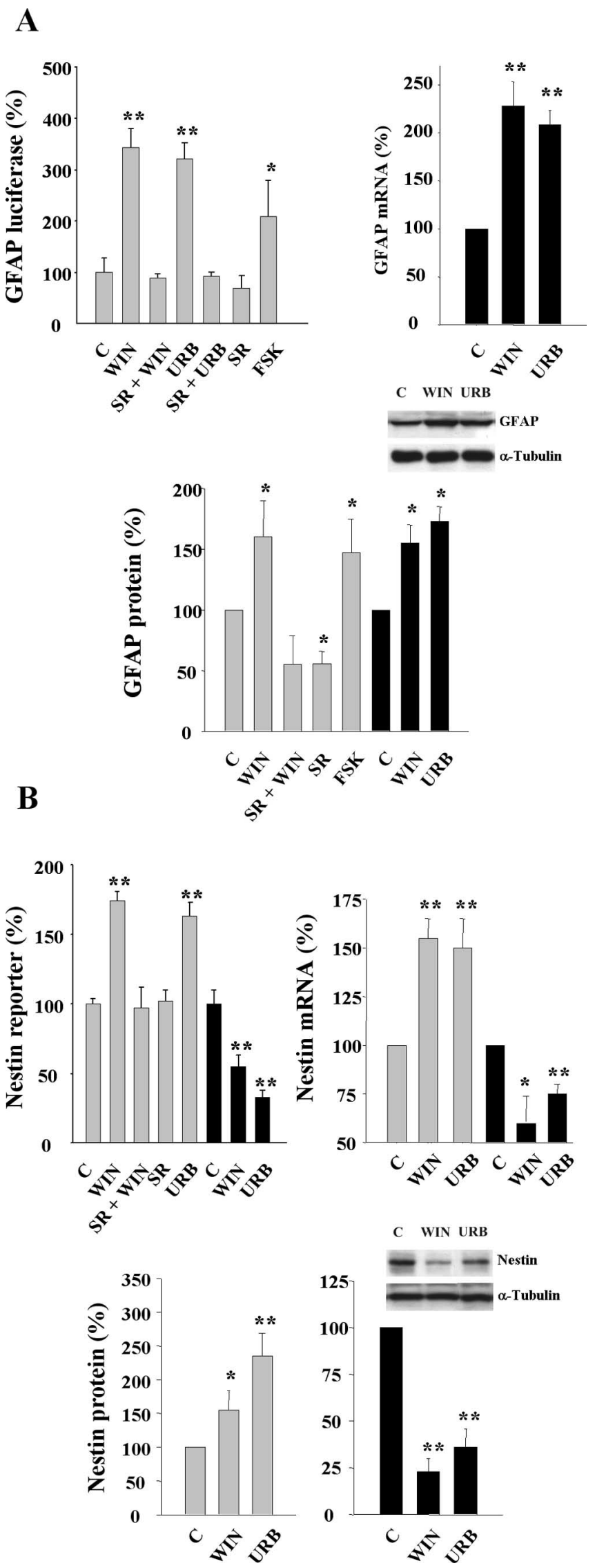

Figure 4. Cannabinoid regulation of GFAP and nestin expression. $\boldsymbol{A}$, Luciferase activity under the control of the GFAP promoter (left) was determined in transfected NPs after $24 \mathrm{~h}$ incubation in the presence of the indicated stimuli. Forskolin (FSK; $5 \mu \mathrm{m}$ ) was used as a positive control. differentiation (Fig. 3A). Likewise, cannabinoids increased the number of cells labeled with the astroglial markers $\mathrm{S} 100 \beta$ and GLAST-1 (Fig. 3 B, C). Cannabinoid action on NP differentiation was blocked by the selective $\mathrm{CB}_{1}$ antagonist SR141716 (Figs. 2, 3), therefore supporting the involvement of the $\mathrm{CB}_{1}$ receptor. The effect of cannabinoid exposure during the complete $8 \mathrm{~d}$ differentiation period (Fig. 2) was analyzed and provided similar results to the values obtained at differentiation day 2 (Fig. 3 ). In addition, cannabinoid influence on NP multipotency was evaluated by using single-cell-derived neurospheres. After differentiation, a large fraction of the progenitors analyzed (68\%) generated the three major lineages of the CNS (neurons, astrocytes, and oligodendrocytes), and treatment with WIN-55,212-2 doubled the number of NPs generating only astroglial cells (Fig. 3D).

\section{Cannabinoid regulation of GFAP and nestin expression}

The impact of cannabinoids on astroglial differentiation prompted us to study the regulation of GFAP and nestin expression. Thus, WIN-55,212-2 and URB597 increased GFAP promoter-driven luciferase activity via $\mathrm{CB}_{1}$ receptor activation (Fig. 4A). Similarly, although to a lower extent, cannabinoid stimulation increased GFAP mRNA and protein levels. In addition, WIN-55,512-2 and URB597 initially (24 h) increased nestin reporter activity, mRNA, and protein levels (Fig. $4 B$ ), which accompanied their proliferative action (see above). At extended differentiation times (day 4), nestin expression was reduced (Fig. $4 B$ ), in line with the reduction of the NP pool (Fig. $2 C$ ) and the increased astroglial differentiation. Overall, these results show that eCBs promote postnatal NP differentiation into astroglial cells in vitro.

Lack of effect of cannabinoids on neural progenitor apoptosis To assess whether the observed progliogenic action of cannabinoids on NPs may be affected by their potential influence in progenitor cell death, we determined apoptosis during cannabinoid challenge. WIN-55,212-2 and URB597 did not reduce cell viability after $2 \mathrm{~d}$ of stimulation, as determined by terminal deoxynucleotidyl transferase-mediated biotinylated UTP nick end labeling (TUNEL) staining (Fig. 5A) and trypan blue exclusion (data not shown). At longer incubation times, apoptotic cells were not evident anymore in the cultures in either the presence or absence of the cannabinoids. We subsequently analyzed whether $\mathrm{CB}_{1}$ receptor deficiency may alter hippocampal apoptosis in vivo. Postnatal hippocampal apoptosis was similar in $\mathrm{CB}_{1}^{-1-}$ mice and their wild-type littermates $(9.9 \pm 2.8$ and $10.5 \pm 2.0 \%$ of TUNEL-positive cells, respectively) and so was the case of adult brain hippocampus (Fig. $5 B$ ). These results confirm the absence of cannabinoid-induced apoptosis in nontransformed neural cells (Galve-Roperh et al., 2000; Guzmán, 2003) and provide additional support to cannabinoid regulation of the NP differentiation process toward the astroglial lineage.

GFAP mRNA levels (right) were determined after cannabinoid stimulation for $4 \mathrm{~d}$. GFAP protein expression (bottom) with the indicated stimuli was determined after $24 \mathrm{~h}$ (gray bars) or $4 \mathrm{~d}$ (black bars). $\boldsymbol{B}$, Nestin reporter activity (left) was determined in transfected NPs after $24 \mathrm{~h}$ (gray bars) or $4 \mathrm{~d}$ (black bars) as above. Nestin mRNA levels (right) and protein levels (bottom) after cannabinoid stimulation for $24 \mathrm{~h}$ (gray bars) or $4 \mathrm{~d}$ (black bars). Densitometric quantification is referred to the corresponding $\alpha$-tubulin signal. Results correspond to three independent experiments. Representative Western blots are shown. Significantly different from controls, ${ }^{*} p<$ $0.05 ; * * 0.01$. 
A

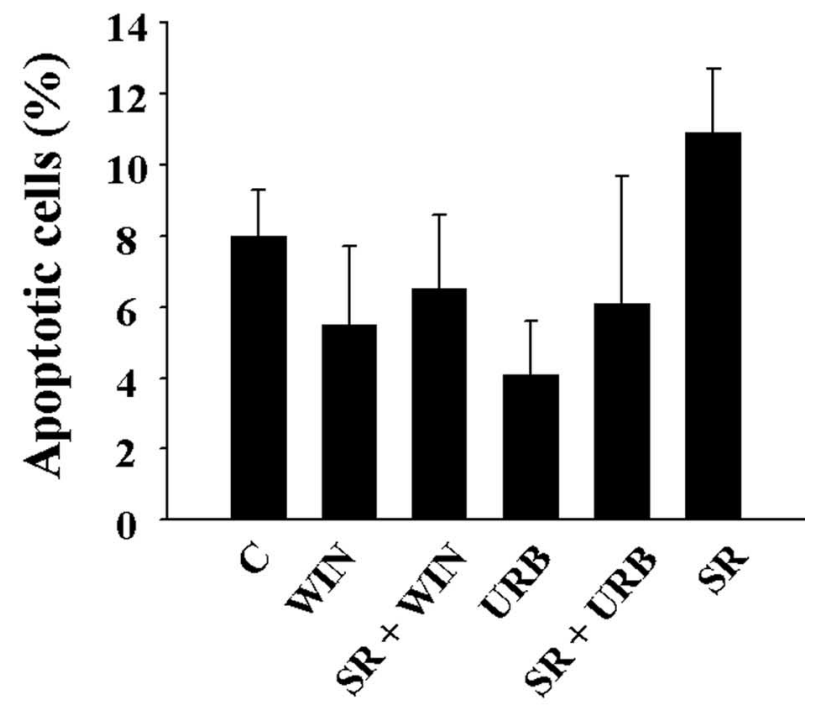

B
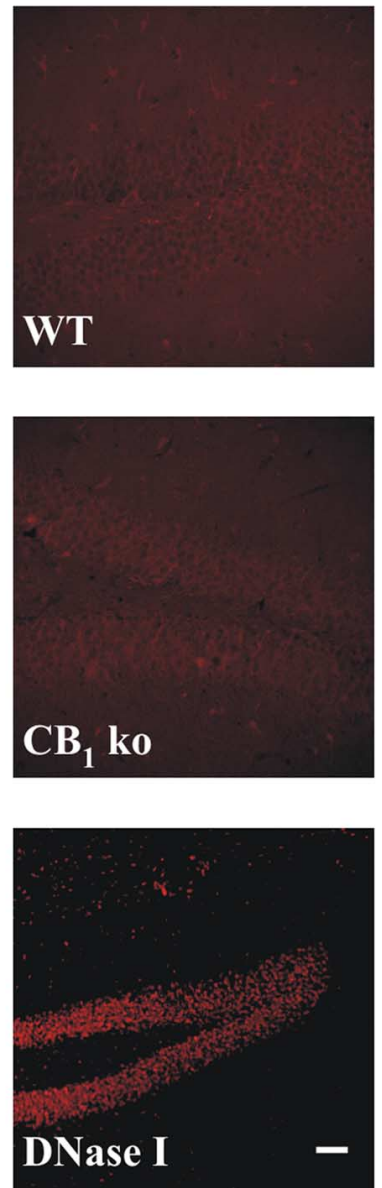

Figure 5. Lack of cannabinoid-induced neural progenitor cell death. A, Quantification of TUNEL staining in NPs stimulated for $48 \mathrm{~h}$ with the indicated cannabinoid agonists or antagonists (as in differentiation experiments). $\boldsymbol{B}$, Apoptosis was determined by TUNEL staining in adult hippocampal brain sections in $C_{1}$ knock-out mice (KO) and their wild-type littermates (WT) ( $n=5$ for each group; representative pictures are shown). DNase-treated sections were used as positive control. Scale bar, $35 \mu \mathrm{m}$.
The endocannabinoid system is involved in the control of postnatal astrogliogenesis in vivo

To investigate the relevance of the $\mathrm{eCB}$ system in the regulation of postnatal NP cell differentiation, we first analyzed $\mathrm{CB}_{1}$ receptor expression by postnatal day $2 \mathrm{NPs}$ in vivo. $\mathrm{CB}_{1}$ was present in nestin-positive cells (Fig. $6 \mathrm{~A}$ ). $\mathrm{RC}^{+}{ }^{+}$and vimentin ${ }^{+}$radial glial cells $($ Fig. $6 B, C$ ) as well as double-positive nestin-GFAP progenitors (Fig. $6 D$ ) also expressed the cannabinoid receptor. Orthogonal reconstructions of confocal images unequivocally evidenced $\mathrm{CB}_{1}$ expression in neural progenitors labeled with antibodies for RC2, vimentin, and phosphorylated vimentin (supplemental Fig. 1 , available at www.jneurosci.org as supplemental material). Specifically, $20.8 \pm 4.0 \%$ of RC2 ${ }^{+}$cells, $15.8 \pm 2.9 \%$ of vimentin $^{+}$ cells, and $30.3 \pm 7.0 \%$ of nestin ${ }^{+} \mathrm{GFAP}^{+}$cells expressed the $\mathrm{CB}_{1}$ receptor. These observations are in agreement with nestin expression by $\mathrm{RC} 2{ }^{+}$radial progenitors, which subsequently loose RC2 expression and acquire GFAP immunoreactivity during development (Kaneko et al., 2000; Gregg and Weiss, 2003; Tramontin et al., 2003; Merkle et al., 2004).

Because the $\mathrm{CB}_{1}$ receptor is expressed by cells with the potential to act as NPs, we next investigated the impact of $\mathrm{CB}_{1}$ deletion in the developing hippocampus by using $\mathrm{CB}_{1}$ knock-out mice (Marsicano et al., 2002). Immunofluorescence quantification of $\mathrm{BrdU}^{+}$cells showed a reduction of NP proliferation in $\mathrm{CB}_{1}^{-/-}$ mice versus wild-type littermates (Fig. $6 E$ ). Moreover, we determined by confocal microscopy and quantification of double $\mathrm{S} 100 \beta^{+} / \mathrm{BrdU}^{+}$or $\mathrm{NeuN}^{+} / \mathrm{BrdU}^{+}$cells whether in vivo differentiation of NPs was affected. This analysis of newly generated cells revealed the existence of reduced astrogliogenesis and increased neurogenesis in $\mathrm{CB}_{1}$-deficient mice. These results support that $\mathrm{CB}_{1}$ expression by postnatal NPs actively participates in the regulation of astroglial differentiation in vivo.

\section{Expression of the endocannabinoid system in adult hippocampal progenitors}

Both the $\mathrm{CB}_{1}$ receptor and FAAH are known to be expressed in the dentate gyrus of the adult brain, with high levels of $\mathrm{CB}_{1}$ in GABAergic interneurons and FAAH displaying a complementary postsynaptic distribution (Tsou et al., 1999; Egertova et al., 2003). However, it is unknown whether undifferentiated neural cells express the components of the $\mathrm{eCB}$ signaling system. We analyzed by confocal microscopy the expression of the $\mathrm{CB}_{1}$ receptor and FAAH in mouse hippocampal sections together with specific neural cell markers. $\mathrm{CB}_{1}$ expression was observed in nestin ${ }^{+}$cells (Fig. $7 A$, top row), as well as in $\mathrm{GFAP}^{+}$cells (Fig. $7 A$, bottom row) and PSA-NCAM ${ }^{+}$cells (data not shown) of the subgranular zone. Conversely, FAAH immunoreactivity was present in nestin $^{+}$and GFAP ${ }^{+}$cells (Fig. 7A), although we could hardly detect its colocalization with PSA-NCAM. Expression of $\mathrm{CB}_{1}$ and FAAH was also evident in double nestin-GFAP-positive cells (type I nestin cells) (Fig. $7 B$ ), which comprise the adult hippocampal neural stem cell population (Seri et al., 2001; Fukuda et al., 2003; Kempermann et al., 2004). Orthogonal reconstruction of confocal sections confirmed the expression of $\mathrm{CB}_{1}$ and FAAH in GFAPimmunoreactive cells of the nestin-GFP hippocampal NPs (supplemental Fig. 2, available at www.jneurosci.org as supplemental material). Importantly, within the nestin ${ }^{+}$cells, the type I subpopulation was selectively enriched in the expression of eCB system elements $\left(\mathrm{CB}_{1}\right.$ expression, $73 \pm 10 \%$ of nestin ${ }^{+} \mathrm{GFAP}^{+}$vs $27 \pm 8 \%$ of nestin ${ }^{+} \mathrm{GFAP}^{-}$cells; FAAH expression, $82 \pm 5 \%$ of nestin ${ }^{+} \mathrm{GFAP}^{+}$cells vs $18 \pm 10 \%$ of nestin ${ }^{+} \mathrm{GFAP}^{-}$cells). Considering that nestin ${ }^{+}$progenitor cells with astroglial features represent the best-defined NP cell population resident in the adult 
dentate gyrus (Alvarez-Buylla and Lim, 2004; Kempermann et al., 2004), these results show that $\mathrm{CB}_{1}$ and FAAH are expressed by hippocampal progenitor cells in vivo, which would allow locally generated eCBs to target NP cells.

\section{The endocannabinoid system is} involved in the control of adult hippocampal astrogliogenesis in vivo The functional relevance of the eCB system in adult neurogenesis was determined in the subgranular zone of the dentate gyrus using $\mathrm{CB}_{1}$ (Marsicano et al., 2002) and FAAH knock-out mice, which possess increased brain levels of eCBs (Cravatt et al., 2001). Adult mice were injected with BrdU and perfused 1 or $25 \mathrm{~d}$ later. Immunofluorescence studies showed that BrdUpositive cells were decreased in $\mathrm{CB}_{1}$ deficient mice, which was significantly different in mice killed shortly after BrdU injection (Fig. $8 A$ ). In agreement, FAAH knock-out mice showed a complementary phenotype with enhanced hippocampal proliferation when compared with wildtype littermates (Fig. $8 A$ ). Similar to the proliferation analysis, $\mathrm{CB}_{1}$ and $\mathrm{FAAH}$ knock-out mice showed opposite cell differentiation patterns (Fig. $8 B$ ). Thus, astroglial differentiation was lower in $\mathrm{CB}_{1}$ deficient mice and enhanced in FAAHdeficient mice. Newly born neuron number remained unaffected (Fig. $8 \mathrm{~B}$ ), despite the observed changes in the percentage of $\mathrm{BrdU}^{+} \mathrm{NeuN}{ }^{+}$cells in both knock-outs (Fig. $8 C$ ). These results confirm that the eCB signaling system plays an active role in the regulation of hippocampal NP proliferation and differentiation in vivo.

\section{Discussion}

Here we provide the first evidence that a functional eCB system present in NPs acts as an instructive progliogenic signal. These findings extend previous observations that suggested that $\mathrm{CB}_{1}$ pharmacological stimulation modulates neurogenesis (Rueda et al., 2002) and NP proliferation (Jin et al., 2004; Aguado et al., 2005). In addition, impaired NP proliferation and neurosphere generation is observed in $\mathrm{CB}_{1}$ deficient mice (Aguado et al., 2005). The role of the eCB system in the regulation of NP differentiation toward the astroglial lineage occurs in parallel with $\mathrm{CB}_{1}$ receptor expression in vivo by postnatal $\mathrm{RC}^{+}$ cells and adult hippocampal nestin type I cells. $\mathrm{CB}_{1}$ deficiency results in impaired astrogliogenesis, whereas high eCB levels in vivo $\left(F A A H^{-1-}\right.$ mice $)$ are associated with an opposite pattern of NP differentiation. Previous data also evidenced a role for the
A
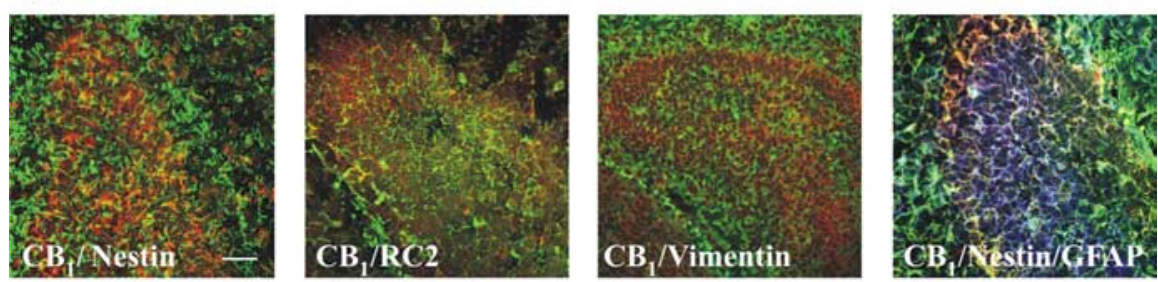

\section{B}
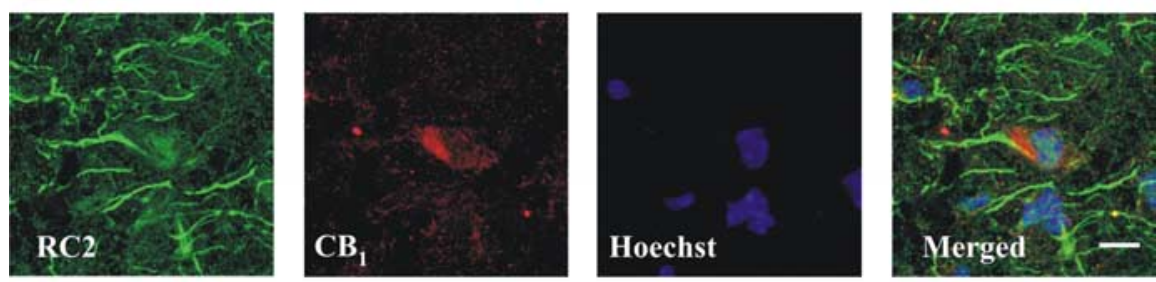

C
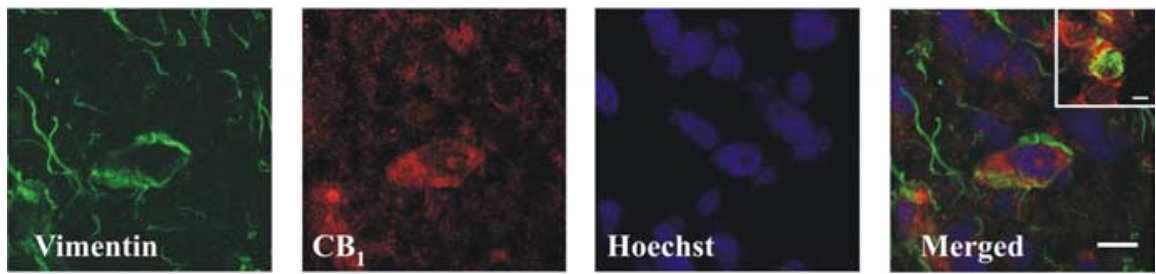

D
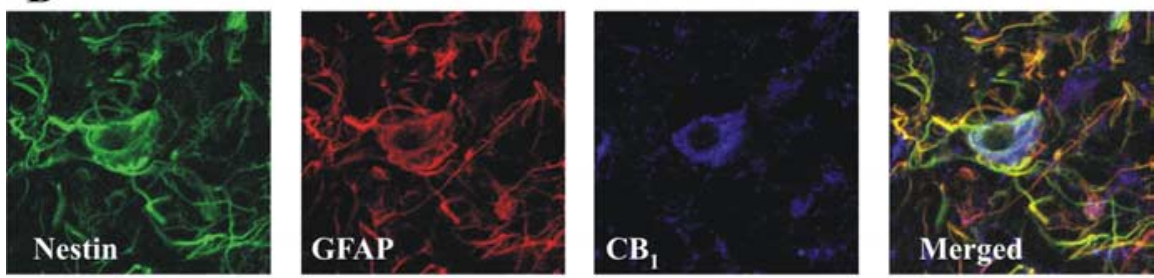

E
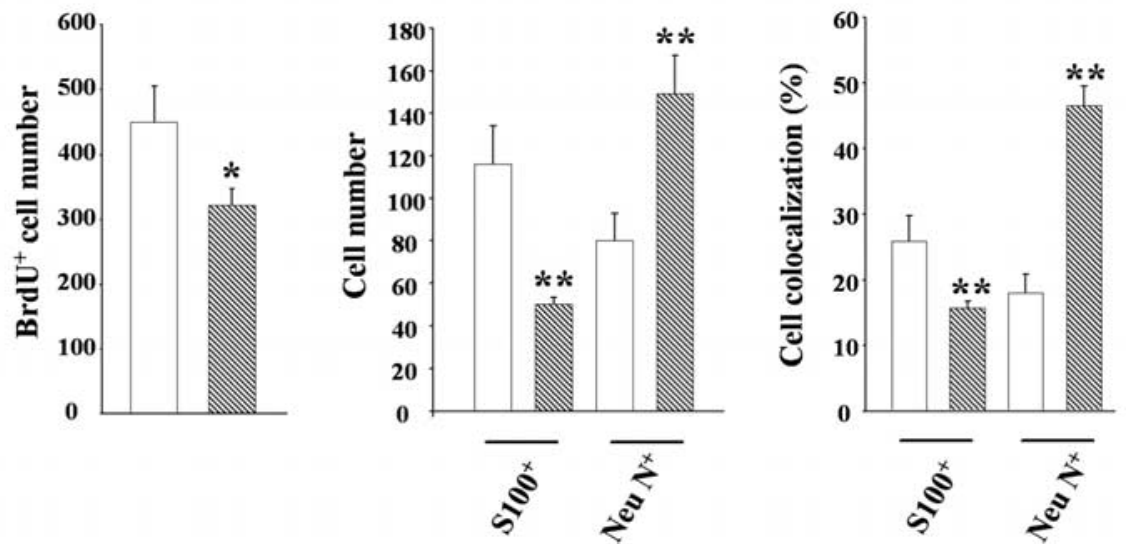

Figure 6. Role of the endocannabinoid system in postnatal astrogliogenesis and neurogenesis in vivo. A, Lowmagnification images of $C B_{1}$ expression in postnatal hippocampus sections stained for nestin, $R C 2$, and vimentin, or nestin and GFAP. Scale bar, $40 \mu \mathrm{m} . \boldsymbol{B}-\boldsymbol{D}, \mathrm{CB}_{1}$ expression (red) in progenitor cells as identified in green color by $\mathrm{RC2}(\boldsymbol{B})$ and vimentin $(\boldsymbol{C})$ immunoreactivity. Double-labeled nestin ${ }^{+}$(green) $\mathrm{GFAP}^{+}$(red) cells $(\boldsymbol{D})$ also express the $\mathrm{CB}_{1}$ receptor (blue). Cells were counterstained with Hoechst (blue). Scale bar, $10 \mu \mathrm{m}$. Inset shows coexpression of $C_{1}$ and phosphorylated vimentin. Scale bar, $6 \mu \mathrm{m}$. $\boldsymbol{E}$, Number of $\mathrm{BrdU}^{+}$cells per section (left), number of BrdU ${ }^{+}$cells that colocalize with $\mathrm{S} 100 \beta$ or NeuN (middle), and percentage of BrdU ${ }^{+}$cells that coexpress $S 100 \beta$ or NeuN (right) in the hippocampus of $C_{1}$ knock-out mice (hatched bars) and their wild-type littermates (white bars). Significantly different from controls, ${ }^{*} p<0.05 ;{ }^{* *} p<0.01$. 
A
Nestin
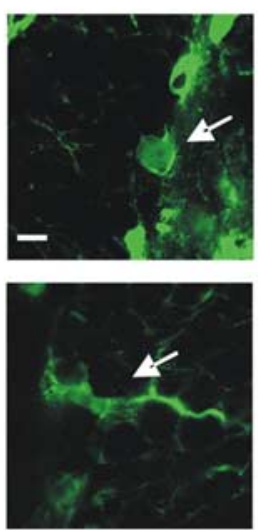

GFAP
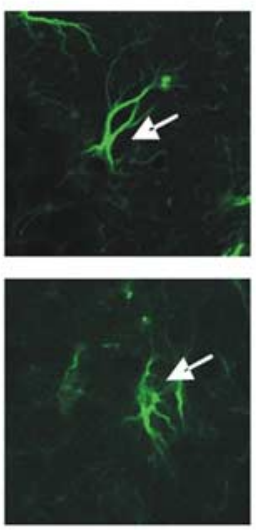

B
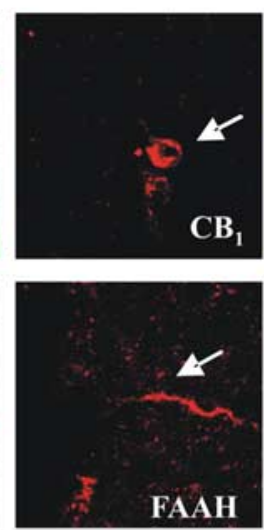

FAAH
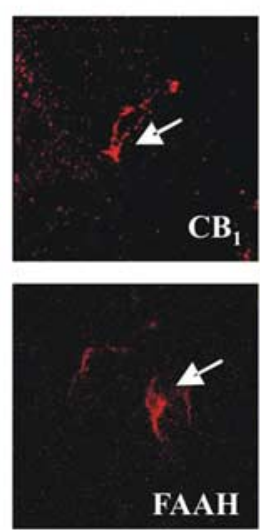

FAAH
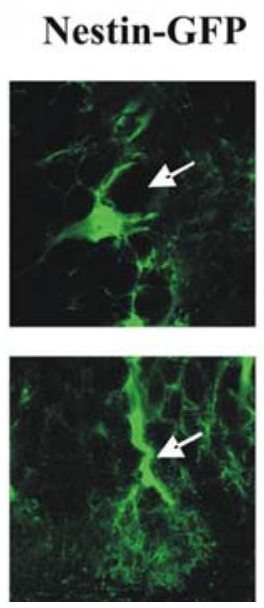

GFAP
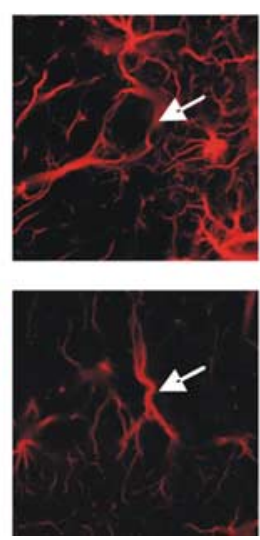

Toto-3
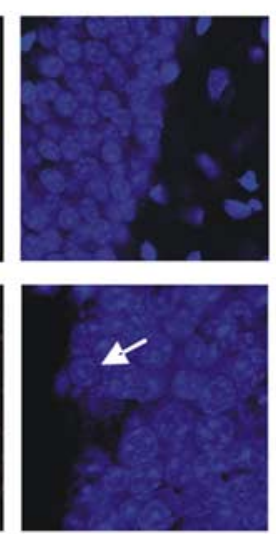

Toto-3
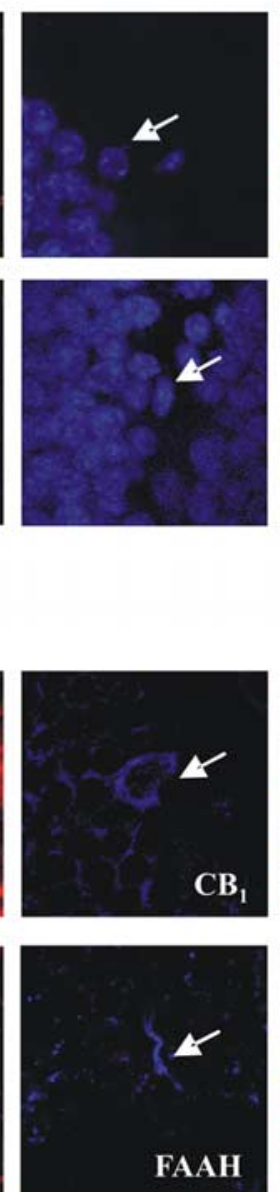

Merged
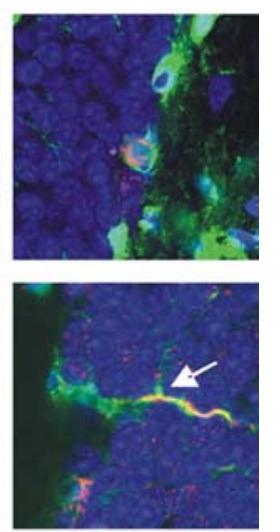

Merged
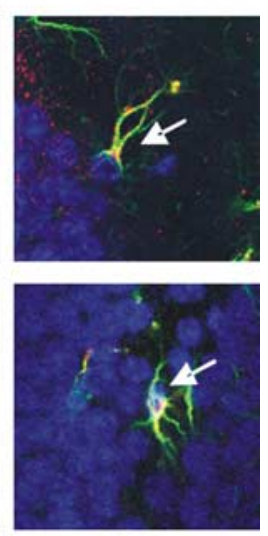

Merged
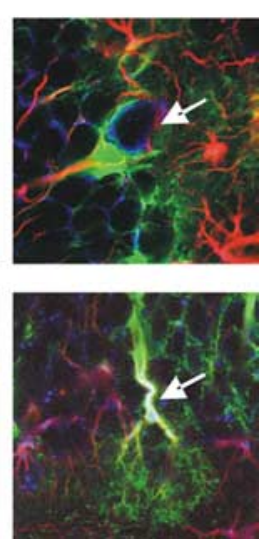

Figure 7. Expression of the $\mathrm{CB}_{1}$ receptor and FAAH in adult hippocampal NPs in vivo. $\boldsymbol{A}$, Expression of $\mathrm{CB}_{1}$ and $\mathrm{FAAH}$ (red) assessed by confocal microscopy as revealed by nestin or GFAP immunoreactivity (green) in mouse hippocampal sections. Cells were counterstained with TOTO-3 iodide (blue). Scale bar, $8 \mu \mathrm{m}$. $\boldsymbol{B}$, Triple labeling showing the expression of $\mathrm{CB}_{1}$ and FAAH (blue) in GFAP-immunoreactive (red) nestin-GFP ${ }^{+}$cells. Representative images are shown.

$\mathrm{CB}_{1}$ receptor in adult NP proliferation, together with the potential involvement of the putative ionotropic eCB receptor, transient receptor potential vanilloid receptor 1 (TRPV1) (Jin et al., 2004). Although our study does not preclude the potential role of TRPV1 receptors in the regulation of NP cell differentiation, the critical role of the metabotropic cannabinoid receptor $\mathrm{CB}_{1}$ is put forward by the existence of impaired astroglial differentiation in
$C B_{1}^{-1-}$ mice and the progliogenic action exerted by WIN-55,212-2, a cannabinoid agonist that does not bind to TRPV1 (Piomelli, 2003). Likewise, a $\mathrm{CB}_{1}$-mediated proliferative NP response has been reported recently by chronic in vivo administration of the synthetic cannabinoid agonist HU-210 ( $\Delta^{8}$-tetrahydrocannabinol dimethyl heptyl) (Jiang et al., 2005). This response was accompanied by increased neurogenesis (astrogliogenesis was not determined) and was proposed to underlie cannabinoid antidepressant actions. Thus, in the restrictive environment toward neurogenesis that features most of the adult brain areas, the proliferative effect of the eCB system in NP cells may result in astrogliogenesis and/or neurogenesis depending on the intensity of cannabinoid stimulation (e.g., endogenous modulation vs pharmacological targeting) or the physiological context of NP regulation (e.g., normal vs injured brain). Considering the neuroprotective role of the eCB system (Mechoulam et al., 2002), its potential role in the regulation of endogenous NPs after brain injury and its precise involvement in the regulation of brain development remain as critical issues to be elucidated. Altogether, these observations open a new field in the investigation of cannabinoid regulation of NPs that, in the future, may provide a useful approach for the pharmacological modulation of adult neurogenesis.

The expression of the eCB system in NPs, together with their action on astroglial differentiation in vitro, suggests a direct mechanism of action that could rely on eCB-initiated signal transduction pathways. During cortical neurogenesis, sustained mitogen-activated protein kinase kinase/extracellular signal-regulated kinase (ERK) signaling is required for neuronal generation and inhibition of gliogenesis (Ross et al., 2003). In this context, although in many cell types $\mathrm{CB}_{1}$ activation leads to ERK stimulation (Guzmán, 2003), cannabinoids inhibit sustained ERK activation in NPs via attenuation of Rap-1/BRaf signaling (Rueda et al., 2002). Alternatively, the eCB system may be targeted by the action of growth factors that are essential for the expansion and regulation of NPs from different brain areas in a variety of developmental stages (Temple, 2001). In particular, bFGF has been shown to regulate neural cell growth by increasing $2 \mathrm{AG}$ generation (Williams et al., 2003). Other potential candidates that may participate in cannabinoid regulation of NPs may involve, e.g., the bone morphogenetic protein family, Notch/Noggin, and leukemia inhibitory factor and other cytokines, which 
are known to be involved in the control of neurogenesis or gliogenesis (Ross et al., 2003; Ever and Gaiano, 2005). To the best of our knowledge, there are not previous evidences pointing to any interaction between these signaling systems and eCBs, and so future research in our laboratory will be devoted to identify the precise cell signaling mechanism involved in eCB action, either directly as progliogenic signals per se (present report) or by influencing the aforementioned endogenous signaling systems.

Overall, the findings presented here add to the previously described roles of eCBs in the CNS, including the modulation of synaptic plasticity and neuronal excitability (Piomelli, 2003), as well as of cell survival (Mechoulam et al., 2002). Astroglial cells are active players of the eCB system physiology. Astrocytes express $\mathrm{CB}_{1}$ receptors (Rodriguez et al., 2001; Guzmán, 2003) and produce eCBs in a regulated manner (Walter et al., 2002), and cannabinoid stimulation protects them from apoptosis (Gómez del Pulgar et al., 2002). Although eCBs act during a limited and short period of time in the modulation of neurotransmitter release and neuronal excitability (Piomelli, 2003), their regulatory effects on NP differentiation are likely to influence neuronal circuitry in a long-term manner. Thus, the ability of the eCB system to modulate NP cell proliferation and differentiation may be of importance during brain development or contribute later to hippocampal adult brain plasticity. In summary, our observations add a novel role for the eCB system regulation of NP cell fate and extend previous evidences suggesting a potential role of the eCB system in brain development and its potential involvement in the pathogenesis of different neurodegenerative disorders.

\section{References}

Aguado T, Monory K, Palazuelos J, Stella N, Cravatt B, Lutz B, Marsicano G, Kokaia Z, Guzmán M, Galve-Roperh I (2005) The endocannabinoid system drives neural progenitor proliferation. FASEB J 19:1704-1706.

Alvarez-Buylla A, Lim D (2004) For the long run: maintaining germinal niches in the adult brain. Neuron 41:683-686.

Cravatt BF, Demarest K, Patricelli MP, Bracey MH, Giang DK, Martin BR, Lichtman AH (2001) Supersensitivity to anandamide and enhanced endogenous cannabinoid signaling in mice lacking fatty acid amide hydrolase. Proc Natl Acad Sci USA 98:9371-9376.

Doetsch F, Caille I, Lim DA, Garcia-Verdugo JM, Alvarez-Buylla A (1999) Subventricular zone astrocytes are neural stem cells in the adult mammalian brain. Cell 97:703-716.

Egertova M, Cravatt BF, Elphick MR (2003) Comparative analysis of fatty acid amide hydrolase and $\mathrm{cb}(1)$ cannabinoid receptor expression in the mouse brain: evidence of a widespread role for fatty acid amide hydrolase in regulation of endocannabinoid signaling. Neuroscience 119:481-496.

Ever L, Gaiano N (2005) Radial "glial" progenitors: neurogenesis and signaling. Current Opin Neurobiol 15:29-33.

Fernández-Ruiz J, Berrendero F, Hernández ML, Ramos JA (2001) The endogenous cannabinoid system and brain development. Trends Neurosci 23:14-20.

Fukuda S, Kato F, Tozuka Y, Yamaguchi M, Miyamoto Y, Hisatsune T (2003) Two distinct subpopulations of nestin-positive cells in adult mouse dentate gyrus. J Neurosci 23:9357-9366.

Galve-Roperh I, Sánchez C, Cortés ML, Gómez del Pulgar T, Izquierdo M, Guzmán M (2000) Antitumoral action of cannabinoids: involvement of sustained ceramide accumulation and extracellular signal-regulated kinase activation. Nat Med 6:313-319.
B

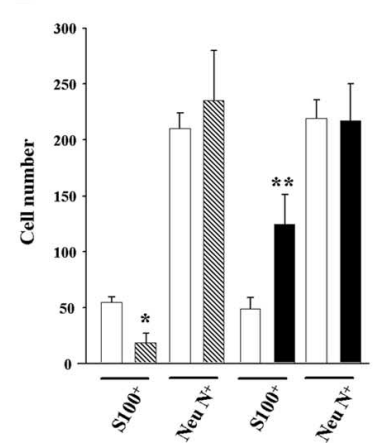

C

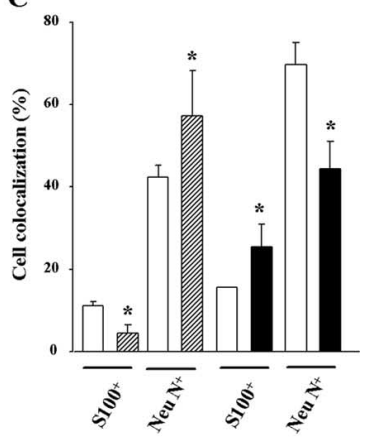

Garcia AD, Doan NB, Imura T, Bush TG, Sofroniew MV (2004) GFAPexpressing progenitors are the principal source of constitutive neurogenesis in adult mouse forebrain. Nat Neurosci 7:1233-1241.

Gómez del Pulgar T, de Ceballos ML, Guzmán M, Velasco G (2002) Cannabinoids protect astrocytes from ceramide-induced apoptosis through the phosphatidylinositol 3-kinase/protein kinase B pathway. J Biol Chem 277:36527-36533.

Gregg C, Weiss S (2003) Generation of functional radial glial cells by embryonic and adult forebrain neural stem cells. J Neurosci 23:11587-11601.

Guzmán M (2003) Cannabinoids: potential anticancer agents. Nat Rev Cancer 3:745-755.

Imura T, Kornblum HI, Sofroniew MV (2003) The predominant neural stem cell isolated from postnatal and adult forebrain but not early embryonic forebrain express GFAP. J Neurosci 23:2824-2832.

Jiang W, Zhang Y, Xiao L, Van Cleemput J, Ji S, Bai G, Zhang Z (2005) Cannabinoid promote embryonic and adult hippocampus neurogenesis and produce anxiolytic- and antidepressant-like effects. J Clin Invest 115:3104-3116.

Jin K, Xie L, Kim SH, Parmentier-Batteur S, Sun Y, Mao XO, Childs J, Greenberg DA (2004) Defective adult neurogenesis in CB1 cannabinoid receptor knockout mice. Mol Pharmacol 66:204-208.

Kaneko Y, Sakakibara S, Imai T, Suzuki A, Nakamura Y, Sawamoto K, Ogawa Y, Toyama Y, Miyata T, Okano H (2000) Musashil: an evolutionally conserved marker for CNS progenitor cells including neural stem cells. Dev Neurosci 22:139-153.

Kempermann G, Jessberger S, Steiner B, Kronenberg G (2004) Milestones of neuronal development in the adult hippocampus. Trends Neurosci 27:447-452.

Laywell ED, Rakic P, Kukekov VG, Holland EC, Steindler D (2000) Identification of a multipotent astrocytic stem cell in the immature and adult mouse brain. Proc Natl Acad Sci USA 97:13883-13888.

Lie DC, Song H, Colamarino SA, Ming G, Gage FH (2004) Neurogenesis in the adult brain: new strategies for central nervous system diseases. Annu Rev Pharmacol Toxicol 44:399-421.

Malatesta P, Hartfuss E, Gotz M (2000) Isolation of radial glial cells by fluorescent-activated cell sorting reveals a neuronal lineage. Development 127:5253-5263.

Marsicano G, Wotjak CT, Azad SC, Bisogno T, Rammes G, Cascio MG, Hermann H, Tang J, Hofmann C, Zieglgansberger W, Di Marzo V, Lutz B (2002) The endogenous cannabinoid system controls extinction of aversive memories. Nature 418:530-534.

Marsicano G, Goodenough S, Monory K, Hermann H, Eder M, Cannich A, Azad SC, Cascio MG, Ortega-Gutierrez S, Van der Stelt M, LópezRodriguez ML, Casanova E, Schütz G, Zieglgänsberger W, Di Marzo V, Behl C, Lutz L (2003) CB1 cannabinoid receptors and on-demand defense against excitotoxicity. Science 302:84-88.

Mechoulam R, Spatz M, Shohami E (2002) Endocannabinoids and neuroprotection. Sci STKE 2002:RE5.

Merkle FT, Tramontin AD, García-Verdugo JM, Alvarez-Buylla A (2004) Radial glia give rise to adult neural stem cells in the subventricular zone. Proc Natl Acad Sci USA 101:17528-17532. 
Mignone JL, Kukekov V, Chiang AS, Steindler D, Enikolopov G (2004) Neural stem and progenitor cells in nestin-GFP transgenic mice. J Comp Neurol 469:311-324.

Noctor SC, Flint AC, Weissman TA, Dammerman RS, Kriegstein AR (2001) Neurons derived from radial cells establish radial units in neocortex. $\mathrm{Na}$ ture 409:714-720.

Panchision DM, Pickel JM, Studer L, Lee S, Turner PA, Hazel TG, McKay RDG (2001) Sequential actions of BMP receptors control neural precursor cell production and fate. Genes Dev 15:2094-2110.

Piomelli D (2003) The molecular logic of endocannabinoid signalling. Nat Rev Neurosci 4:873-884.

Pixley SK, de Vellis J (1984) Transition between immature radial glia and mature astrocytes studied with a monoclonal antibody to vimentin. Brain Res 317:201-209.

Rakic P (2003) Developmental and evolutionary adaptations of cortical radial glia. Cereb Cortex 13:541-549.

Rodriguez JJ, Mackie K, Pickel VM (2001) Ultrastructural localization of the $\mathrm{CB}_{1}$ cannabinoid receptor in $\mu$-opioid receptor patches of the rat caudate putamen nucleus. J Neurosci 21:823-833.

Ross SE, Greenberg ME, Stiles CD (2003) Basic helix-loop-helix factors in cortical development. Neuron 39:13-25.

Rueda D, Navarro B, Martínez-Serrano A, Guzmán M, Galve-Roperh I (2002) The endocannabinoid anandamide inhibits neuronal progenitor cell differentiation through attenuation of the Rap 1/B-Raf/ ERK pathway. J Biol Chem 277:4645-4650.

Seri B, García-Verdugo JM, McEwen BS, Alvarez-Buylla A (2001) Astrocytes give rise to new neurons in the adult mammalian hippocampus. J Neurosci 21:7153-7160.

Sommer I, Schachner M (1981) Monoclonal antibodies (O1 to O4) to oligodendrocyte cell surfaces: an immunocytological study in the central nervous system. Dev Biol 83:311-327.

Temple S (2001) The development of neural stem cells. Nature 414:112-117.

Tramontin AD, García-Verdugo JM, Lim DA, Alvarez-Buylla A (2003) Postnatal development of radial glia and the ventricular zone (VZ): a continuum of the neural stem cell compartment. Cereb Cortex 13:580-587.

Tsou K, Mackie K, Sañudo-Peña MC, Walker JM (1999) Cannabinoid CB1 receptors are localized primarily on cholecystokinin-containing gabaergic interneurons in the rat hippocampal formation. Neuroscience 93:969-975.

Walter L, Franklin A, Witting A, Moller T, Stella N (2002) Astrocytes in culture produce anandamide and other acylethanolamides. J Biol Chem 277:20869-20876.

Williams E, Walsh FS, Doherty P (2003) The FGF receptor uses the endocannabinoid signaling system to couple to an axonal growth response. J Cell Biol 160:481-486. 